\title{
THE INTEGRATED NATURAL SCIENCES APPROACHES TO THE PROTECTION OF MEDIEVAL RUINS
}

\section{NOVOTNÝ Jakub ${ }^{1}$, BLÁHA Jiř́2}

${ }^{1}$ Jakub Novotný, Institute of Theoretical and Applied Mechanics of the Czech Academy of Sciences https://orcid.org/0000-0003-2162-3218

2 Jiř́ Bláha, Institute of Theoretical and Applied Mechanics of the Czech Academy of Sciences https://orcid.org/0000-0002-9403-1427

ABSTRACT: The aim of this paper is to present the Report of innovative restoration techniques, technologies and materials used in conservation in the context of natural sciences and heritage science of the RUINS Project. First, the specifics of preservation and maintenance of ruins are briefly described. Subsequently, the context of natural sciences and the new scientific discipline of heritage science, including the link to innovation, are indicated. The paper then presents the structure of the report and an example of one record representing one specific technique. Record structure is ready to be transferred to versatile data set so it could be converted into an updatable online database in the future.

KEY WORDS: Natural sciences, innovations, heritage conservation and preservation, ruin 


\section{Jakub Novotný, Jiř́ Bláha}

\section{Introduction - specifics of preservation and maintenance of ruins}

According to literature the term ruin means the object preserved in an incomplete state, sometimes deliberately constructed to give the impression of an intact structure that has decayed. Such architecture arises as a result of the loss of the original purpose of the building. Usually these objects were left to long-term deterioration and there was no reason to rebuild or remove them. Inside urban areas ruins are therefore exceptional, because there is an effort to maximize the use of space. In cities there is deliberate devastation of buildings by speculative owners or due to poor maintenance in order to destroy the building and release the land for new construction. This is one of the negative phenomena.

Czech preservationist Ondřej Šefcü ${ }^{1}$ states that ruined constructions in the classical sense are remnants of once remarkable historical buildings with the added value of a romantically perceived gradual disintegration. These buildings lack basic functional elements such as roofs, gutters, windows, doors etc. Determination torso construction, however, is not clear. Monument care must therefore be applied separately to individual buildings.

Technical problems to be solved while maintaining the buildings in general: protection against climatic and biological influences and, last but not least, before the people themselves.

On the basis of practical experience, some interventions can be designed to help in ruins preservation:

1. Prevent excessive moisture in the building (drainage, runoff, temporary or permanent roofing).

2. Adjacent greenery must be removed, especially if it interferes the remaining masonry with roots. However, this must be done with caution, as roots can support the construction.

3. More distant trees are rather positive and lead to the preservation of the picturesqueness of the site.

4. The consolidation of core masonry, which has not been built to resist weather effects, may also be necessary.

5. In order to make the building accessible, it is necessary to set up new paths, stairs or embedded structures. Social or technical background is also essential. All these structures, however, should minimize the impact on the historic values as well as possible to fit in context.

There is never the ideal solution, it is always a compromise. The well balance of exploitation and proper maintenance of the building is the need and should therefore be thoroughly judged by the professional public.

Ruins are a valuable source of authentic scientific information and have a specific emotional basis. In 2 nd half of the 18th century in English came an interest (proto-Romanticism), which began to repair and maintain the ruins intentionally. In the period of purism (2nd half of the

1 Ševců O., Problémy při opravách torzálních památek. Poznatky památkáře, Sborník přednášek z odborného semináře STOP, STOP, Czech 2017. 
19th century), there was a strong tendency to complete the ruins in to its "original" form. Heritage conservation represent complex problem. We must respect and protect the value of ruins as a full-fledged historical source capable of wide-ranging testimony. Therefore, there are no general rules and each case requires a distinct approach. However, there are general principles and recommendations that have emerged from practice ${ }^{2}$ these principles include:

- Classification of the object;

- Architectural style of ruin;

- Heritage values;

- Social function of ruin;

- Concept of repair works;

- Conservation;

- Reconstruction;

- Implementation of building repairs;

- Appropriate mode of use.

As we see, responsible preservation and maintenance of historical ruins requires, in addition to the usual methods of care for historical buildings and works of art, the application of completely specific procedures. Their uncommon nature is based on the fact that normally it is unusual to preserve a building in an incomplete state. In order to cope with weather and other environmental conditions, a building needs to have a completed system of finishing elements such as roofs and roofing, wall toppings, plasters or protective coatings. The application of these standard elements, however, often contradicts the prevailing conceptual requirement to "protect a ruin as a ruin", and therefore the conservation of partially preserved buildings entails a number of unusual technical problems. To address these unusual technical problems helps science, or the results of the individual disciplines of science.

\section{Natural science - basic breakdown}

Natural science can be described as the systemic enterprise that builds and organizes knowledge in the form of testable explanations and predictions about the universe $e^{3}$. The natural science is commonly divided to:

- Physical science - branch of natural science that studies non-living systems

- Astronomy;

- Physics;

- Chemistry;

- Earth Science.

2 Sokol J. Dudík T. Štulc J., Ochrana, údržba a stavební úpravy zřícenin hradů, Státní ústav památkové péče v Praze, Czech 1998.

3 https://en.wikipedia.org/wiki/Outline_of_natural_science 
- Life science - branch of natural science that studies living systems

- Biology;

- Ecology.

The need to incorporate technicals and humanities in the field of cultural heritage research has led to the formation and emergence of a new scientific discipline in recent decades. One of the leading platforms for shaping and operating this scientific field in Europe is the emerging research distribution infrastructure E-RIHS (European Research Infrastructure for Heritage Science). The current definition of this scientific discipline comes from this platform: Heritage science is the interdisciplinary domain of scientific study of heritage. Heritage science draws on diverse humanities, sciences and engineering disciplines. It focuses on enhancing the understanding, care and sustainable use of heritage so it can enrich people's lives, both today and in the future. Heritage science is an umbrella term encompassing all forms of scientific enquiry into human works and the combined works of nature and humans, of value to people. (Heritage Science on Wikipedia, n. d.).

For the natural sciences and subsequent engineering disciplines, innovations are essential for practical application (not only) in the field of torsal architecture.

\section{Innovative restoration techniques, technologies and materials used in conservation}

An overview of all tools available for investigation, preservation and presentation of historical ruins would be too extensive. So for practical output within RUINS project realized review of them must be necessarily selective. Priority has been given to those methods and procedures that are among the most used in the process of ruin protection and preservation. Preference was given also to the methods used at the workplaces of the members of the consortium, as well as to original results of the applied research achieved at these workplaces. For this reason, especially analytical and diagnostic methods are significantly represented in the Report of innovative restoration techniques, technologies and materials used in conservation.

The individual records were arranged in such a way that the descriptive characteristics of each method are presented first, then the extent of use or application and also the necessary degree of intervention. For a practical assessment a briefly summarizing of their advantages and disadvantages is namely important. Those interested in more information will appreciate keywords for internet searching, summary of the literature on the subject and links to important websites. In most cases, the examples of real applications are included which can further clarify the scope of use. The report includes these categories:

- Survey, recording and presentation methods:

- Recording methods:

- 3D scanning of details;

- Aerial archaeological prospection;

- Electronic tacheometry; 
- Digital photogrammetry;

- Drone photography;

- Laser scanning;

- 360 degree photography.

- Visualization techniques:

- 3D modelling;

- GIS;

- Scale modelling.

- Diagnostic methods:

- Hidden spaces and cavities:

- Endoscopy;

- Ground-penetrating radar;

- Thermography.

- Material testing:

- Loading jack;

- Pilodyn penetrometer;

- Pin pushing;

- Schmidt impact hammer.

- Damage inspection:

- Acoustic tracing;

- Doppler interferometry;

- Portable X-ray generator;

- Resistograph;

- Ultrasonic testing.

- Material analyses:

- Capacitance moisture measuring;

- FTIR spectroscopy;

- Ion chromatography;

- Nuclear magnetic resonance;

- Optical microscopy;

- Pull-off testing;

- Raman spectroscopy;

- Resistance moisture measuring;

- Scanning electron microscopy; 
- Soil compaction assessment;

- Thermal analysis;

- X-ray computed tomography;

- X-ray diffraction;

- X-ray fluorescence spectroscopy.

- Remedial interventions:

- Masonry consolidation and stabilization:

- Fiber reinforced composites;

- Local replacement of masonry;

- Retaining walls.

- Renders and surface treatment:

- Custom made lime;

- Nanolime treatment;

- Patination;

- Plaster and render replication.

- Wall tops and roofs:

- Hidden roofs;

- Lead capping;

- Soft (turf) capping.

- Maintenance and risk management:

- Regular inspections.

- Modern facilities:

- Info-panels;

- Retractable roofs;

- Scenic illumination;

- Transparent protective roofs;

- Transparent floors.

The details and form of individual records are best demonstrated on a specific sample tool Loading jack for compression strength measuring. 


\begin{tabular}{|c|c|}
\hline Method & Loading jack for compression strength measuring \\
\hline Kind & Diagnostic \\
\hline Basic description & $\begin{array}{l}\text { A portable device to measure mechanical properties of wood using small size jack inserted } \\
\text { in a pre-drilled hole and designed to determine the current mechanical properties: } \\
\text { strength and modulus of deformability in compression parallel to the grain. In the test, } \\
\text { the dependence of the force on deformation is measured while symmetrically arranged } \\
\text { jaws are being pushed apart in a radial borehole with a } 12 \mathrm{~mm} \text { diameter. }\end{array}$ \\
\hline Specification & $\begin{array}{l}\text { The device has been developed by ITAM AS CR for the specific needs of field surveys. } \\
\text { During the measurement, the force is scanned and recorded. It is calibrated to the real } \\
\text { force of the jaws pushing apart and simultaneously related to the measured distance of } \\
\text { jaw displacement. The correlations between the compression strength parallel to the grain } \\
\text { and the strength of standard specimens is determined in compliance with EN } 408 \text { range } \\
\text { in the interval R } 2=0.7-0.9 \text { based on the wood species. The relations were described by } \\
\text { usable linear regression models. The modulus of elasticity cannot be calculated directly } \\
\text { from the diagram; the modulus of deformability was established using the angle of the } \\
\text { curve fit through the linear part of the force record and deformation. Commonly, the } \\
\text { measurement is performed at four different depths below the surface. The holes into the } \\
\text { material to be tested are carefully drilled at selected places to enable further assessment of } \\
\text { the timber condition, e.g. the timber quality based on the obtained core, sawdust, as well } \\
\text { as video inspection. }\end{array}$ \\
\hline Range of use & $\begin{array}{l}\text { Developed for the purpose of on-site inspections. Designed only for soft wood species } \\
\text { commonly used in timber constructions (roofs, ceilings, log walls), namely spruce, fir, } \\
\text { pine and larch. Requires } 150 \times 150 \mathrm{~mm} \text { free area for drill. }\end{array}$ \\
\hline Intervention rate & Semi-destructive (less invasive) \\
\hline Main advantages & $\begin{array}{l}\text { Thanks to wireless connection with a laptop gives results immediately. The holes can be } \\
\text { used for future measurements. }\end{array}$ \\
\hline Negatives or risks & In the case of decorated ceiling beams, the holes must be sealed after the testing. \\
\hline References & $\begin{array}{l}\text { Drdácký M., Kloiber M., In-situ compression stress-deformation measurements along the } \\
\text { timber depth profile. In Structural Health Assessment of Timber Structures, Book Series: } \\
\text { Advanced Materials Research 778, Trans Tech Publications, Switzerland 2013, pp. 209- } \\
216 . \\
\text { Kloiber M., Drdácký M. Tippner J., Hrivnák J., Conventional compressive strength parallel } \\
\text { to the grain and mechanical resistance of wood against pin penetration and microdrilling } \\
\text { established by in-situ semidestructive devices, [in:] Materials and Structures, 2015, 48(10): } \\
\text { pp. 3217-3229. }\end{array}$ \\
\hline Available at & ITAM CAS \\
\hline Keywords & Defectoscopy, material testing, soft wood \\
\hline
\end{tabular}

4 Drdácký M., Kloiber M., In-situ compression stress-deformation measurements along the timber depth profile. In Structural Health Assessment of Timber Structures, Book Series: Advanced Materials Research 778, Trans Tech Publications, Switzerland 2013, pp. 209-216.

5 Kloiber M., Drdácký M. Tippner J., Hrivnák J., Conventional compressive strength parallel to the grain and mechanical resistance of wood against pin penetration and microdrilling established by in-situ semidestructive devices, [in:] Materials and Structures, 2015, 48(10): pp. 3217-3229. 


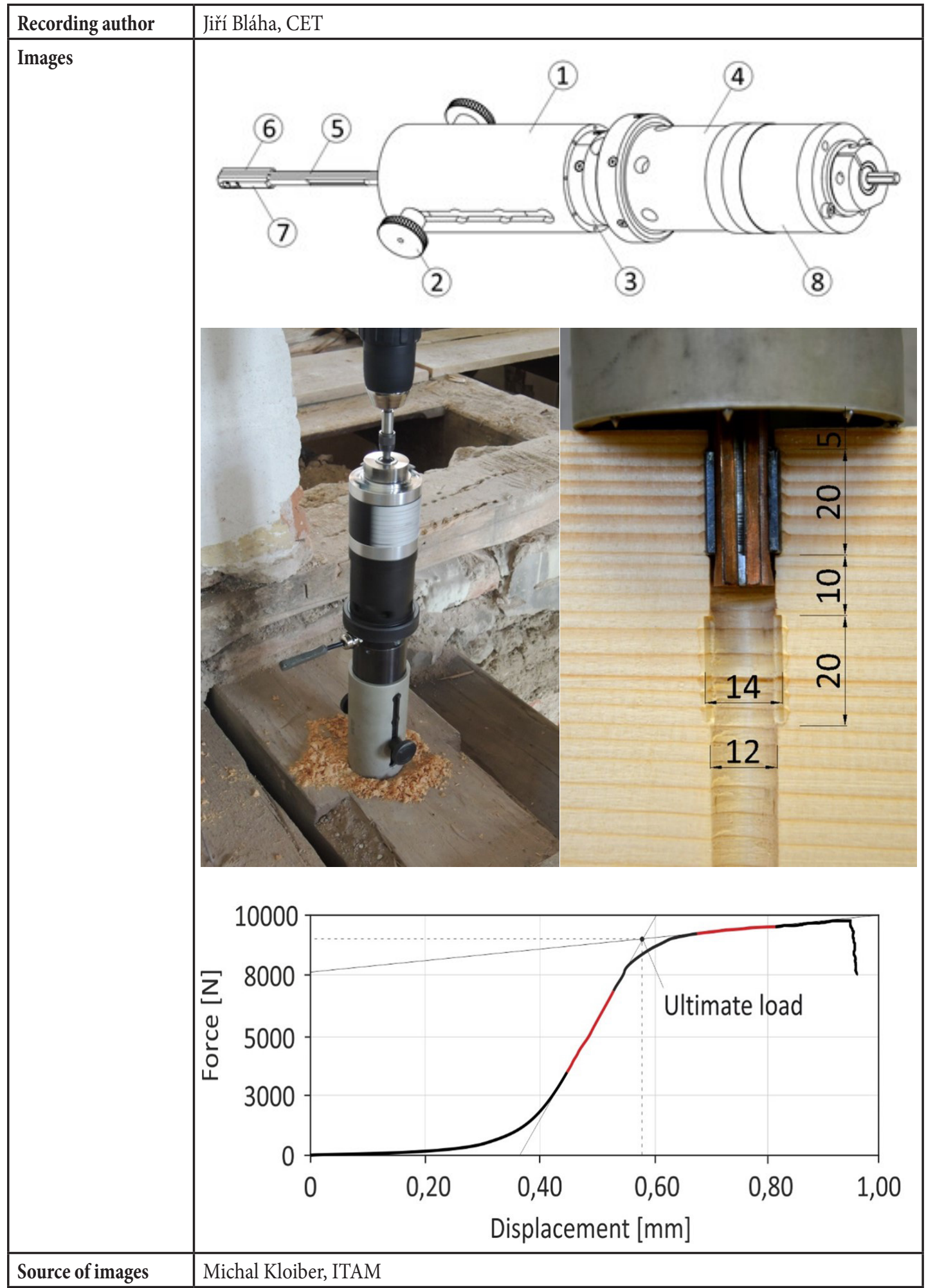




\section{Example of application}

\begin{tabular}{|c|c|}
\hline Site Specification & Stř́ibro, house Nr. 305 \\
\hline Localization & Stř́bro Nr. 16, Tachov District, Plzeň Region, Czech Republic \\
\hline Owner and management & Private owner \\
\hline Affected part & Timber log rooms embedded in brick wall town house. \\
\hline Intervention reasons & $\begin{array}{l}\text { Detailed survey of log walls built in two different time periods }(1490 / 91 \mathrm{~d}, 1731 / 31 \mathrm{~d}) \text { as } \\
\text { known from dendrochronological dating. }\end{array}$ \\
\hline Intervention extent & Semi-destructive \\
\hline Date of intervention & 2016-12-06 \\
\hline Time consumption & 3 hours \\
\hline Results & $\begin{array}{l}\text { The medieval timber walls in room A can continue to perform their structural function. } \\
\text { The deformed walls on the northern and eastern side of the room B (Baroque) would } \\
\text { require such a heavy repair, coupled with the significant amount of replacement of } \\
\text { the original material that a complete exchange would appear to be a more appropriate } \\
\text { solution. }\end{array}$ \\
\hline Evaluation & $\begin{array}{l}\text { The on-site application of loading jack helped to determine actual bearing capacity of } \\
\text { the preserved log walls. It has been acquired in a less-invasive way. }\end{array}$ \\
\hline References & $\begin{array}{l}\text { Bláha J., Kloiber M., Hrivnák J., Stavebnè-technický průzkum roubených stěn domu čp. } \\
305 \text { ve Střibře (okr. Tachov), Research report, CET Telč } 2016 \text {. } \\
\text { Karel T., Kratochvílová A., Nález roubené konstrukce pozdně gotického domu ve Stříbře } \\
\text { (Ruská, čp. 305), [in:] Průzkumy památek II/2017, pp. 69-78. }\end{array}$ \\
\hline Images & \\
\hline
\end{tabular}




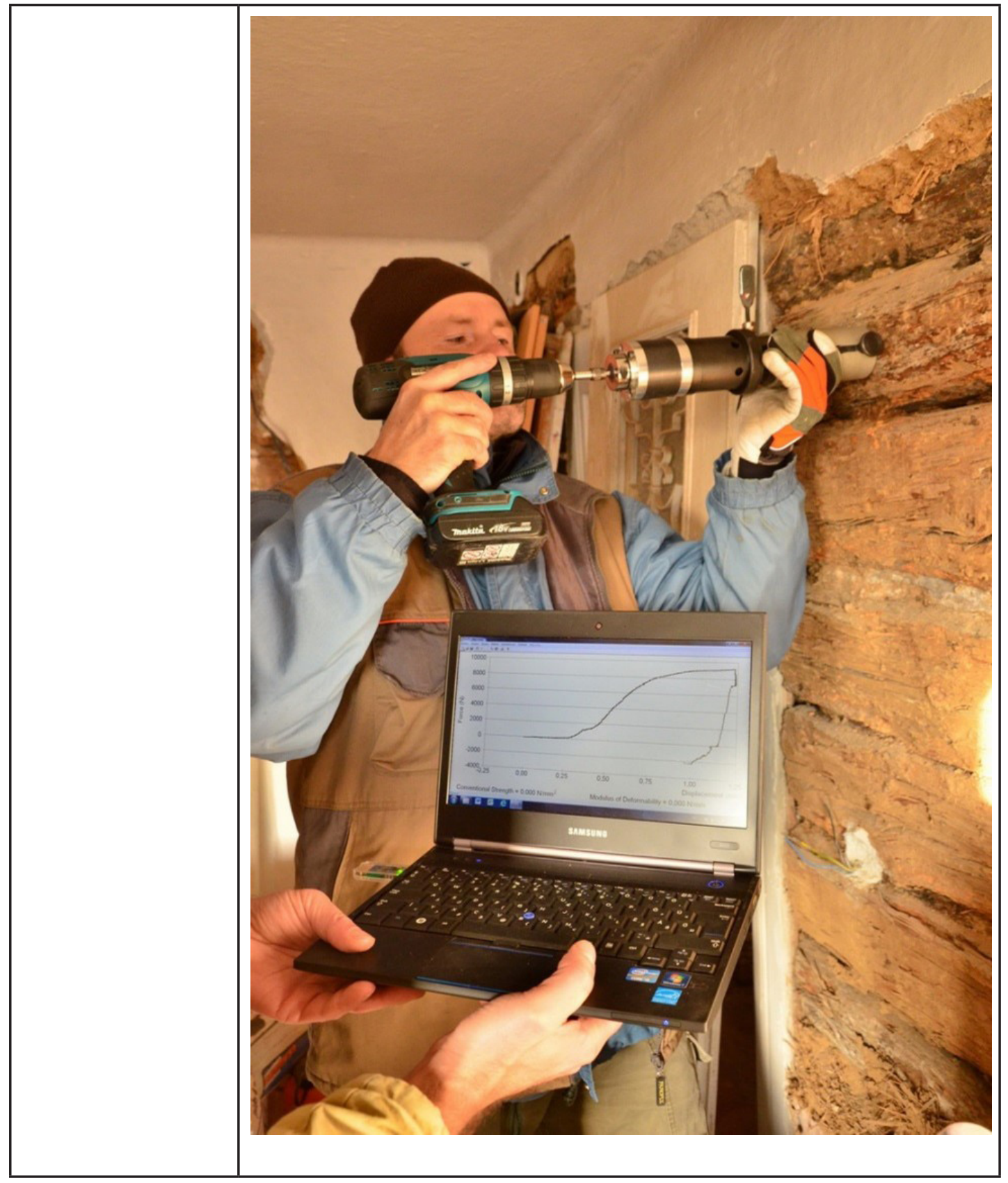




\section{Conclusion}

Preservation and maintenance of ruins require a specific approach based on a systemic insight to the whole issue. This is an approach that is characteristic of the whole heritage science. Natural sciences are reflected in the protection of ruins mainly through technical innovations.

There is a wide range of supporting techniques, technologies and materials that can be used so it occurs beneficial to have an overview of suitable techniques and materials to apply with the specification of area of use (ruins in our case). The overview contained in the presented report is selective, so it is appropriate not to take it as a final list, but more as an initial corpus that can be supplemented and updated on the basis of new knowledge and experience as different techniques, technologies and materials evolve over time. The structure of records is ready to be transferred to a database so it could be converted into an updatable online list in the future. Such a maintained publicly available database can be a useful support tool for the area of preservation and maintenance of ruins.

\section{Acknowledgement}

This article was created within the project RUINS (CE902), Interreg Central Europe.

\section{Author contributions}

All parts of the article were elaborated by both authors. 


\section{Bibliography}

Bláha J., Kloiber M., Hrivnák J., Stavebně-technický průzkum roubených stěn domu čp. 305 ve Stř́brére (okr. Tachov), Research report, CET Telč 2016.

Drdácký M., Kloiber M., In-situ compression stress-deformation measurements along the timber depth profile. In Structural Health Assessment of Timber Structures, Book Series: Advanced Materials Research 778, Trans Tech Publications, Switzerland 2013, pp. 209-216.

E-RIHS, n.d. [on/line], viewed: 9.10.2019, http://www.e-rihs.eu/.

Heritage Science on Wikipedia, n.d. [on/line], viewed: 9.10.2019, https:/en.wikipedia.org/wiki/ Heritage_science.

Karel T., Kratochvílová A., Nález roubené konstrukce pozdně gotického domu ve Stříbře (Ruská, čp. 305), [in:] Průzkumy památek II/2017, pp. 69-78. Kloiber M., Drdácký M. Tippner J., Hrivnák J., Conventional compressive strength parallel to the grain and mechanical resistance of wood against pin penetration and microdrilling established by in-situ semidestructive devices, [in:] Materials and Structures, 2015, 48(10): pp. 3217-3229.

Natural Science on Wikipedia, n.d. [on/line], viewed: 28.8.2020, https:/en.wikipedia.org/wiki/ Outline_of_natural_science.

Novotný J., Bláha J., A system approach to medieval ruins management. Proceedings of the conference System approaches '19. System Perspective on Modern Technologies, Prague: University of Economics, 2019, pp. 19-25, ISBN 978-80-245-2350-7.

Report assessing innovative restoration techniques, technologies and materials used in conservation, DT1.3.1, 04/2018. [on/line], viewed: 20.08.2020, https://www.interreg-central.eu/Content. Node/RUINS/D.T1.3.1-Report-innovative-techniques-technologies-materials.pdf.

Transnational rules of sustainable preservation, protection and conservation of historical ruins. D.T1.4.1, 12/2018. [on/line], viewed: 8.11.2019, https://www.interreg-central.eu/Content. Node/D.T1.4.1-Transnational-rules-of-sustainable-preservation--protec. 